\title{
Transcriptomic and Targeted Metabolomic Analysis Identifies Genes Controlling for Early Bolting and Flowering in Angelica Sinensis
}

\section{Mengfei Li ( $\sim$ Imf@gsau.edu.cn )}

Gansu Agricultural University https://orcid.org/0000-0003-3035-4427

Jie Li

Gansu Agricultural University

\section{Ruyu Yao}

Chinese Academy of Medical Sciences \& Peking Union Medical College Institute of Medicinal Plant

Development

\section{Ling Jin}

Gansu University of Traditional Chinese Medicine

\section{Hua Xing}

Gansu Agricultural University

\section{Delong Yang}

Gansu Agricultural University

Jianhe Wei

Chinese Academy of Medical Sciences \& Peking Union Medical College Institute of Medicinal Plant

Development

\section{Paul W. Paré}

Texas Tech University

\section{Research article}

Keywords: Angelica sinensis, early bolting and flowering, transcriptomic analysis, gibberellin metabolism, sucrose metabolism

Posted Date: December 1st, 2020

DOI: https://doi.org/10.21203/rs.3.rs-113695/v1

License: (a) (1) This work is licensed under a Creative Commons Attribution 4.0 International License.

Read Full License 


\section{Abstract}

Background: The root of the perennial herb Angelica sinensis is a widely used source for traditional Chinese medicines. While the plant thrives in cool-moist regions of western China, early bolting and flowering (EBF) for young plants, significantly reduces root quality and yield. Approaches to inhibit EBF by changes in physiology during the vernalization process have been investigated, however the mechanism for activating EBF has not been identified. Here, transcript profiles for bolted and unbolted plants (BP and UBP, respectively) are compared.

Results: A total of over 72,000 unigenes were detected with ca. 2,600 differentially expressed genes (DEGs) observed in the BP compared with UBP. While various signaling pathways participate in flower induction, it is genes associated with floral development and the sucrose pathway that are observed to be coordinated in EBF plants, to coherently up and down regulate flowering genes that activate and inhibit flowering, respectively. Down-stream signal accumulation including gibberellic acids and sucrose metabolites were also monitored by HPLC-MS/MS for EBF plants.

Conclusions: The signature transcripts pattern for the developmental pathways that drive flowering provides insight into the molecular signals that activate plant EBF.

\section{Background}

Angelica sinensis is a perennial herb that is distributed mainly in cool-moist regions of western China at elevations ranging from 2,200 to 3,000 $\mathrm{m}$ above sea level [1-3]. Roots (Danggui) are prepared as a traditional Chinese tonic reported to nourish the blood and harmonize vital energy. Over 140 root metabolites have been identified, including polysaccharides, organic acids, phthalides, and essential oils $[4,5]$. These compounds confer pharmacological activities including: anti-inflammatory, antioxidant, anticancer and cardio-cerebrovascular effects [6-10].

Due to an increasing demand for traditional Chinese medicines, $A$. sinensis is farmed to meet commercial demand [3]. For industrialized planting, seeds are sown in early summer, plants are collected in Fall and overwintering indoors; the following spring, seedlings are planted for vegetative growth and either harvested in Fall of the second year to obtain non-lignified roots (Fig. S1A) or kept in the field till midsummer of the third year for seed collection (Fig. S1B). Early bolting and flowering (EBF) occur in the second year for up to $40 \%$ of the plants, substantially reducing root yield and quality due to lignification and reduced concentrations of bioactive compounds $[11,12]$.

In order to reduce $A$. sinensis EBF, several internal (e.g. seed maturity, seedling age and weight) as well as external factors (e.g. altitude, light and nutrients) have been identified [1, 13-15]. For example, the purple stemmed (Mingui No.1) and green-stemmed phenotype (Mingui No.2), albeit quite rare, lower EBF rates compared to the more common purple-stemmed phenotype [3]. And for EBF to occur, the plant must experience vernalization [i.e. an extended period of cool weather $\left(0\right.$ to $\left.5^{\circ} \mathrm{C}\right)$ ] and long-day (LD) conditions (>12 hr/day)]; thus, avoiding vernalization or LD conditions can reduce EBF [16-18]. Planting medium- 
maturity seeds, shortening seedlings rearing time and reducing seedling size can also reduce EBF $[15,16$, 19]. Cultivating at higher elevations, reducing nitrogen and phosphorus exogenous applications are both external factors that reduce EBF $[13,14,16]$.

The transition from vegetative growth to flowering involves multiple signaling pathways that are transcriptionally regulated including: photoperiodic, autonomous/vernalization, sucrose, and gibberellin (GA) pathways. All pathways converge by increasing the expression of the two meristem identity genes: SUPPRESSOR OF OVEREXPRESSION OF CONSTANS1 (SOC1) that is also known as AGAMOUSLIKE 20 (AGL2O) and $L E A F Y$ ( $L F Y$ ). SOC1 and $L F Y$, in turn, regulate the floral homeotic genes to produce the floral organs $[20,21]$. The photoperiodic pathway is initiated by phytochromes and cryptochromes. The interaction of photoreceptors with a circadian clock activates the expression of the gene CONSTANS (CO) that encodes a zinc-finger transcription factor that promotes flowering. In the dual autonomous/vernalization pathway, flowering occurs either in response to internal signals, the production of a fixed number of leaves, or to low temperatures that reduces the expression of the flowering repressor gene FLOWERING LOCUSC (FLC). The sucrose pathway reflects the metabolic state of the plant and sucrose stimulates flowering by increasing $L F Y$ expression. Lastly, the GA pathway can participate in early flowering and for flowering under noninductive short days.

Besides the previously mentioned developmental pathways that promote flowering, Arabidopsis mutants that exhibit early flowering have revealed the involvement of genes that repress flowering. For example, EMBRYONIC FLOWER1 (EMF1) and EMF2 act as strong flowering repressors [22]; CURLY LEAF (CLF) by preventing the expression of the floral meristem identity gene $A G A M O U S(A G)$ during vegetative growth [23]; EARLY BOLTING IN SHORTDAYS (EBS) participates in the regulation of flowering time by specifically repressing the expression of FLOWERING LOCUS T (FT) [24]; Cyclic dof factor 2 (CDF2) delays flowering by repressing $C O$ transcription [25]; and MicroProtein $1 A(M I P 1 A)$ and MIP1B repress flowering by forming heterodimeric complexes [26].

During $A$. sinensis seedling vernalization with winter storage, levels of soluble sugars, amino acids and organic acids increase as well as nitrate reductase activity [27]. In contrast, during the photoperiodic stage of plant growth, soluble sugars and protein levels are reduced. The amounts of amino acids, $\mathrm{GA}_{3}$, zeatin riboside and polyamines as well as the activities of peroxidase and polyphenoloxidase increase in bolting plants (BP) compared with unbolted plants (UBP) [28]. Although ca. 5,100 genes have been differentially expressed in the apical meristem of vegetative growth compared to flower buds of early flowering and 13 DEGs were involved in photoperiodic, vernalization, sucrose and GA pathway [29], early bolting-dependent changes that impact genes expression and GAs metabolism have not been mapped and identified. In this study, functional leaves, and lateral roots of BP and UBP were measured by transcriptomic analysis and 40 DEGs associated with EBF were mapped on pathways associated with flower control. Gene expression levels were validated by qRT-PCR and down-stream GA metabolites were profiled by HPLC-MS/MS.

\section{Results}




\section{Global gene analysis}

A robust data set was collected (Fig. S2) and after data filtering, 60.7 and 52.4 million high-quality reads were obtained for the BP and UBP, respectively; 44.7 and 37.4 million unique reads as well as 7.8 and 6.4 million multiple reads were mapped. From the 72,502 compiled genes and annotated against the databases including NR, SwissProt, KEGG, KOG, and GO (Table 1 and Table 2, Fig. S3-S7), 2,645 DEGs were obtained (Fig. S8). Of these 2,645 DEGs, 369 were unidentified by SwissProt, KOG, GO and KEGG databases. Of the 2,276 identified DEGs, 738 and 846 were up- and down-regulated, respectively. Based on biological function and physiological characteristics, genes were divided into 11 categories: photosynthesis/energy (79), primary metabolism (285), secondary metabolism (80), hormone biosynthesis (34), bio-signaling (201), cell morphogenesis (197), polynucleotide biosynthesis (87), transcription factor (167), translation (119), transport (233), and stress response (102) (Fig. 1). Based on flower driving genes characterized in higher plants [21], 40 DEGs (29 UR and 11 DR) were identified as potential regulatory genes for EBF (Fig. 1). 
Table 1

Summary of sequencing data for $A$. sinensis transcriptome

\begin{tabular}{|c|c|c|}
\hline & Bolted & Unbolted \\
\hline \multicolumn{3}{|l|}{ Unfiltered data } \\
\hline Data of reads number (million) & 60.73 & 52.48 \\
\hline Reads length & 150 & 150 \\
\hline GC (\%) & 44.69 & 45.12 \\
\hline Data of reads number $\times$ read length (million) & 9110 & 7872 \\
\hline Q20(\%) & 98.50 & 98.47 \\
\hline Q30(\%) & 95.25 & 95.18 \\
\hline \multicolumn{3}{|l|}{ Filtered data ${ }^{1}$} \\
\hline Data of reads number (million) & 60.66 & 52.41 \\
\hline Data of reads number $\times$ read length (million) & 9098 & 7862 \\
\hline Q20(\%) & 98.56 & 98.53 \\
\hline Q30(\%) & 95.34 & 95.26 \\
\hline \multicolumn{3}{|l|}{ Mapped data ${ }^{2}$} \\
\hline Data of unique mapped reads (million) & 44.70 & 37.40 \\
\hline Data of multiple mapped reads (million) & 7.80 & 6.40 \\
\hline Mapping ratio (\%) & 86.56 & 83.57 \\
\hline \multicolumn{3}{|l|}{ Compiled data } \\
\hline Total number of unigenes & \multicolumn{2}{|l|}{72,502} \\
\hline Total Length (bp) (million) & \multicolumn{2}{|l|}{64.14} \\
\hline N50 (bp) & \multicolumn{2}{|l|}{1,534} \\
\hline Max length (bp) & \multicolumn{2}{|l|}{15,601} \\
\hline Min length (bp) & \multicolumn{2}{|l|}{201} \\
\hline Average Length (bp) & \multicolumn{2}{|l|}{884} \\
\hline GC content $(\%)$ & \multicolumn{2}{|l|}{41.17} \\
\hline \multicolumn{3}{|c|}{${ }^{1}$ Reads with a quality score $<30$ and length $<60$ bp were excluded; } \\
\hline
\end{tabular}


Table 2

Database searches for collected $A$. sinensis nucleotide sequences

\begin{tabular}{|lll|}
\hline BLASTx searching against specific platforms & Values & Percentage (\%) \\
\hline NR & 44,708 & 61.66 \\
\hline SwissProt & 30,471 & 42.03 \\
\hline KOG & 22,959 & 31.67 \\
\hline KEGG & 18,056 & 24.90 \\
\hline GO & 12,473 & 17.20 \\
\hline
\end{tabular}

\section{DEGs Linked with Bolting and Flowering}

Eight DEGs directly participate in floral development including: SOC1, MADS8, AGL8, AGL 12, DEFA, AP1, $A P 2$ and $A N T$ (Table 3). The RELs of these genes were consistent with RPKM values, with up regulation of 1.1-, 2.4-, 6.8-, 1.1-, 1.3- and 1.3-fold for SOC1, MADS8, AGL8, AGL12, DEFA and AP1, respectively, in bolted compared to unbolted plants; down-regulation of 0.6- and 0.9-fold was observed for $A P 2$ and $A N T$ (Fig. 2A). 
Table 3

Bolting/flowering genes differentially expressed in bolted and unbolted $A$. sinensis.

\section{Gene name Protein name}

$\log ^{2}$ Ratio ( $\left.\mathrm{B}_{\mathrm{RPKM}} / \mathrm{UB}_{\mathrm{RPKM}}\right)$

\section{Floral development (8)}

Genes favor flowering

\begin{tabular}{lll} 
SOC1 & MADS-box protein SOC1 & 1.06 \\
MADS8 & MADS-box transcription factor 8 & 7.21 \\
\hline AGL8 & Agamous-like MADS-box protein AGL8 & 4.16 \\
AGL12 & Agamous-like MADS-box protein AGL12 & 3.42 \\
DEFA & Floral homeotic protein DEFICIENS & 1.11 \\
AP1 & Floral homeotic protein APETALA 1 & 4.29
\end{tabular}

Genes disfavor flowering

$\begin{array}{lll}\text { AP2 } & \text { Floral homeotic protein APETALA } 2 & -6.14\end{array}$

ANT AP2-like ethylene-responsive transcription factor ANT $\quad-3.27$

\section{Sucrose pathway (11)}

\section{Genes favor flowering}

\begin{tabular}{lll} 
SUS1 & Sucrose synthase isoform 1 & 1.31 \\
\hline SUS3 & Sucrose synthase 3 & 1.40 \\
\hline INVA & Alkaline/neutral invertase A, mitochondrial & 1.41 \\
\hline INVB & Probable alkaline/neutral invertase B & 1.22 \\
\hline INVE & Alkaline/neutral invertase E, chloroplastic & 1.09 \\
\hline SUS7 & Sucrose synthase 7 & -2.70 \\
\hline AMY1.1 & Alpha-amylase & 1.03 \\
\hline BAM1 & Beta-amylase 1, chloroplastic & 1.62 \\
\hline BAM3 & Beta-amylase 3, chloroplastic & 1.05 \\
\hline BAM9 & Inactive beta-amylase 9 & 1.30 \\
\hline Genes disfavor flowering & -1.83 \\
\hline INV Inh & Invertase inhibitor \\
\hline GA pathway (7)
\end{tabular}




\begin{tabular}{|c|c|c|}
\hline Gene name & Protein name & $\log ^{2}$ Ratio $\left(B_{\mathrm{RPKM}} / \mathrm{UB}_{\mathrm{RPKM}}\right)$ \\
\hline \multicolumn{3}{|c|}{ Genes favor flowering } \\
\hline KO & Ent-kaurene oxidase, chloroplastic & 2.04 \\
\hline GA200X1 & Gibberellin 20 oxidase 1 & 1.77 \\
\hline \multicolumn{3}{|c|}{ Genes disfavor flowering } \\
\hline GA2OX1 & Gibberellin 2-beta-dioxygenase 1 & -1.41 \\
\hline GA20X6 & Gibberellin 2-beta-dioxygenase 6 & 2.53 \\
\hline GA20X8 & Gibberellin 2-beta-dioxygenase 8 & 1.65 \\
\hline GAl & DELLA protein GAI & -3.49 \\
\hline GAIP & DELLA protein GAIP & 2.15 \\
\hline \multicolumn{3}{|c|}{ Photoperiodic induction (14) } \\
\hline \multicolumn{3}{|c|}{ Genes favor flowering } \\
\hline co3 & Zinc finger protein $\mathrm{CO} 3$ & 2.58 \\
\hline COL2 & Zinc finger protein CONSTANS-LIKE 2 & 3.5 \\
\hline$H D 3 A$ & Protein HEADING DATE 3A & 13.41 \\
\hline FTIP1 & FT-interacting protein 1 & 2.13 \\
\hline$F D$ & Protein FD & 3.26 \\
\hline$S V P$ & MADS-box protein SVP & -1.25 \\
\hline \multicolumn{3}{|c|}{ Genes disfavor flowering } \\
\hline COL3 & Zinc finger protein CONSTANS-LIKE 3 & -2.79 \\
\hline $\operatorname{COL} 16$ & Zinc finger protein CONSTANS-LIKE 16 & -1.33 \\
\hline$A S 1$ & Transcription factor AS1 & -2.23 \\
\hline CDF2 & Cyclic dof factor 2 & 3.03 \\
\hline MIP1A & B-box domain protein 30 & 2.58 \\
\hline MIP1B & B-box domain protein 31 & 3.50 \\
\hline$E F M$ & EARLY FLOWERING MYB PROTEIN & 1.12 \\
\hline
\end{tabular}

Eleven DEGs associated with sucrose pathway including: Suc metabolism (SUS1, SUS3, SUS7, INVA, INVB, INVE and INV Inh) and starch metabolism (AMY1.1, BAM1, BAM3 and BAM9) (Table 4) were 
transcriptionally regulated so as to favor flowering in BPs. The RELs were consistent with RPKM values, with down-regulated 0.3-fold for the INV Inh gene, and up-regulated 1.3- to 6.1-fold for the other 10 genes in the BP compared to the UBP (Fig. 2B). 
Table 4

Sequences of primer used in the qRT-PCR analysis

\begin{tabular}{|c|c|c|}
\hline Gene name & Sequences $\left(5^{\prime}\right.$ to $\left.3^{\prime}\right)$ & Amplicon size (bp) \\
\hline \multirow[t]{2}{*}{$A C T$} & Forward: TGGTATTGTGCTGGATTCTGGT & \multirow[t]{2}{*}{109} \\
\hline & Reverse: TGAGATCACCACCAGCAAGG & \\
\hline \multicolumn{3}{|c|}{ Floral development } \\
\hline \multirow[t]{2}{*}{ SOC1 } & Forward: CGAAACGGCGAAATGGACTG & \multirow[t]{2}{*}{200} \\
\hline & Reverse: CTGAATGTCTTGCCCAGCAG & \\
\hline \multirow[t]{2}{*}{ MADS8 } & Forward: GAGATGAGCGGAGGCCAAAG & \multirow[t]{2}{*}{101} \\
\hline & Reverse: AGCTTCCCCATGTTCTGTTCC & \\
\hline \multirow[t]{2}{*}{ AGL8 } & Forward: CGGAGCAACAAAACCAAGAGAG & \multirow[t]{2}{*}{102} \\
\hline & Reverse: CTCCGATGTTGCGTATGGCTT & \\
\hline \multirow[t]{2}{*}{ AGL 12} & Forward: ATGGATGAACTGCATGTGCTTG & \multirow[t]{2}{*}{191} \\
\hline & Reverse: ACCGGAACATCAATGTTACTAAACC & \\
\hline \multirow[t]{2}{*}{$D E F A$} & Forward: ACTCCGGAATGAGATCGGC & \multirow[t]{2}{*}{116} \\
\hline & Reverse: GCTCGCGTATGATGGCAAC & \\
\hline \multirow[t]{2}{*}{$A P 1$} & Forward: TCGAAGTCCTGCAACGGAAC & \multirow[t]{2}{*}{200} \\
\hline & Reverse: CAGTTGGTTGTTCTGCCCC & \\
\hline \multirow[t]{2}{*}{$A P 2$} & Forward: CTCTTCGACAGCCACCTTCA & \multirow[t]{2}{*}{163} \\
\hline & Reverse: AGGCTCCAACTGACTCGAAC & \\
\hline \multirow[t]{2}{*}{$A N T$} & Forward: GCGAGGCGTAACAAAGACA & \multirow[t]{2}{*}{153} \\
\hline & Reverse: CTGCTGTGGGAACTGATCTAGC & \\
\hline \multicolumn{3}{|c|}{ Sucrose pathway } \\
\hline \multirow[t]{2}{*}{ SUS1 } & Forward: ATGAAGTCCACACAGGAAGCC & \multirow[t]{2}{*}{112} \\
\hline & Reverse: CGACGACAAGGTGATGAGTG & \\
\hline \multirow[t]{2}{*}{ SUS3 } & Forward: GGAGAGAAGACTAACGTGCCT & \multirow[t]{2}{*}{169} \\
\hline & Reverse: CGCGTAGCACTCTACTAGCC & \\
\hline SUS7 & Forward: TGACTTTATCGTCATCGGTTGG & 166 \\
\hline
\end{tabular}




\begin{tabular}{|c|c|c|}
\hline Gene name & Sequences ( $5^{\prime}$ to $\left.3^{\prime}\right)$ & Amplicon size (bp) \\
\hline & Reverse: AGAGCCGTGTTGAGTGTCT & \\
\hline \multirow[t]{2}{*}{ INVA } & Forward: TAAGTTGTGCGGTTTGCGAG & \multirow[t]{2}{*}{174} \\
\hline & Reverse: АCTACACTCCTACCGCCAGT & \\
\hline \multirow[t]{2}{*}{$I N V B$} & Forward: TTGCCGTCCTTTTCACCTCC & \multirow[t]{2}{*}{132} \\
\hline & Reverse: CTCATGCCCAAACTGTGACCT & \\
\hline \multirow[t]{2}{*}{ INVE } & Forward: CAATTCGGGAAATCGAGTCCT & \multirow[t]{2}{*}{145} \\
\hline & Reverse: CTGCCGCACTAACACTTTCT & \\
\hline \multirow[t]{2}{*}{ AMY1.1 } & Forward: AAATCCAGACACCGGCACTC & \multirow[t]{2}{*}{128} \\
\hline & Reverse: АTCTCCAGCCAACGAATCCA & \\
\hline \multirow[t]{2}{*}{ BAM1 } & Forward: GGGAAGCTCAGGTACCACTT & \multirow[t]{2}{*}{127} \\
\hline & Reverse: GCACACATTTCСTCTGCTCC & \\
\hline \multirow[t]{2}{*}{ BAM3 } & Forward: AGTCTCCGAGCAAGAAATTCG & \multirow[t]{2}{*}{127} \\
\hline & Reverse: TGCTATGTGGCCGAGATGAC & \\
\hline \multirow[t]{2}{*}{ BAM9 } & Forward: TTCCCGCAGAAAATCTGTTGA & \multirow[t]{2}{*}{118} \\
\hline & Reverse: TGCGGAAATTGCTTTTGCGT & \\
\hline \multirow[t]{2}{*}{ INV Inh } & Forward: TCGAGCTTTATGATGATGCCCTC & \multirow[t]{2}{*}{180} \\
\hline & Reverse: TAGCATTGTTCCTGGCGGTT & \\
\hline \multicolumn{3}{|l|}{ GA pathway } \\
\hline \multirow[t]{2}{*}{ KO } & Forward: ACTTGCTGTGAGTGGCCCG & \multirow[t]{2}{*}{104} \\
\hline & Reverse: AAGGAGGGAGATTCGAGGGTG & \\
\hline \multirow[t]{2}{*}{ GA200X1 } & Forward: AACCGTTCTACCAAGCGAAT & \multirow[t]{2}{*}{175} \\
\hline & Reverse: CCGGAGAGAAAGCCTCCTATG & \\
\hline \multirow[t]{2}{*}{ GA2OX1 } & Forward: ACCAACACATTGATTCCCCTC & \multirow[t]{2}{*}{171} \\
\hline & Reverse: GGACATAGGTGAAGAGAAAAACTTG & \\
\hline \multirow[t]{2}{*}{ GAl } & Forward: GTATTCGGCTGGTCCACGTT & \multirow[t]{2}{*}{144} \\
\hline & Reverse: AGCCAGCCACCTTACCAAAG & \\
\hline
\end{tabular}




\begin{tabular}{|c|c|c|}
\hline Gene name & Sequences ( $5^{\prime}$ to $\left.3^{\prime}\right)$ & Amplicon size (bp) \\
\hline \multirow[t]{2}{*}{ GA20X6 } & Forward: GCCTTGACTTGCTAAGGGTG & \multirow[t]{2}{*}{152} \\
\hline & Reverse: AGCCTCAGACCAAGAGAGTT & \\
\hline \multirow[t]{2}{*}{ GA20X8 } & Forward: AGTTGGCAGAAATCTTAGCGG & \multirow[t]{2}{*}{119} \\
\hline & Reverse: CTCCGGTATTGGACATGGTGG & \\
\hline \multirow[t]{2}{*}{ GAIP } & Forward: TGTATCATСССССТССТGСТ & \multirow[t]{2}{*}{132} \\
\hline & Reverse: GCATTCACTATCTCCTTTGCTTCC & \\
\hline \multicolumn{3}{|c|}{ Photoperiodic induction } \\
\hline \multirow[t]{2}{*}{$\mathrm{co3}$} & Forward: CTCAGCTTATGGGACCACC & \multirow[t]{2}{*}{101} \\
\hline & Reverse: CGAGCACGTTGGCGAC & \\
\hline \multirow[t]{2}{*}{ COL2 } & Forward: TTCATCCCCAGCAAGAGCAG & \multirow[t]{2}{*}{131} \\
\hline & Reverse: GGATACAGAAACGCTGTGGC & \\
\hline \multirow[t]{2}{*}{$H D 3 A$} & Forward: GAAAGTCCGAGGCCATCAGC & \multirow[t]{2}{*}{121} \\
\hline & Reverse: CGGCAAAGTCTCTAGTATTGAATTG & \\
\hline \multirow[t]{2}{*}{ FTIP1 } & Forward: AACGCTGACAAAATCACAAGCA & \multirow[t]{2}{*}{193} \\
\hline & Reverse: GATTCCACTCGGGGTTCACT & \\
\hline \multirow[t]{2}{*}{$F D$} & Forward: TACCACCCCCACCACTAAAC & \multirow[t]{2}{*}{160} \\
\hline & Reverse: AGAGCTGCTGCTAGGGTTG & \\
\hline \multirow[t]{2}{*}{ SVP } & Forward: GCCGGATTAAGTCGCGTGAT & \multirow[t]{2}{*}{150} \\
\hline & Reverse: TGGGATTAGCTTTCCACCTTTAGA & \\
\hline \multirow[t]{2}{*}{ COL3 } & Forward: AAAGGTACAGAGCAAAGCGTG & \multirow[t]{2}{*}{127} \\
\hline & Reverse: CCTTGAGCTTCATCATTGCGT & \\
\hline \multirow[t]{2}{*}{ COL16 } & Forward: GATGGGTCAGCAGAGACGAT & \multirow[t]{2}{*}{116} \\
\hline & Reverse: TCGCTGTTTGTCATTTCCGT & \\
\hline \multirow[t]{2}{*}{$A S 1$} & Forward: ATCCCGACCAACCTGCTTC & \multirow[t]{2}{*}{138} \\
\hline & Reverse: AAGTTGGGAGTGGAGCTGTT & \\
\hline$C D F 2$ & Forward: TCGATCCCCAACAACGAAGAG & 196 \\
\hline
\end{tabular}




\begin{tabular}{|c|c|c|}
\hline Gene name & Sequences ( $5^{\prime}$ to $\left.3^{\prime}\right)$ & Amplicon size (bp) \\
\hline & Reverse: ATGTTGTTGGACCACCCCTC & \\
\hline \multirow[t]{2}{*}{ MIP1A } & Forward: GCGATACAAGGGTTCATGCTG & \multirow[t]{2}{*}{104} \\
\hline & Reverse: GAGTCCGATGAGATAGCGGTG & \\
\hline \multirow[t]{2}{*}{ MIP1B } & Forward: TGATTGCCACGCTCTAACCC & \multirow[t]{2}{*}{156} \\
\hline & Reverse: GGCCTAATGAGTTGGTTGGTG & \\
\hline \multirow[t]{2}{*}{ HDR1 } & Forward: GCAAGAGATCAGGACAGGGAG & \multirow[t]{2}{*}{146} \\
\hline & Reverse: TGGTTTTCCAGCATTGTGTTTTG & \\
\hline \multirow[t]{2}{*}{$E F M$} & Forward: TGACTTGCACCGGAGATTTGT & \multirow[t]{2}{*}{200} \\
\hline & Reverse: TTTGAACTCGGGCCAACCA & \\
\hline
\end{tabular}

Since GA accumulation can promote flowering, transcripts that encode for GA biosynthesis were screened for up regulation in EBF plants. The 7 DEGs that are associated with GA signals include: GA biosynthesis (KO, GA20X1, GA20X6, GA20X8 and GA200X1) and GA mediated signaling pathway (GA/and GAIP) (Table 3). The RELs of the 7 genes were consistent with RPKM values, with up-regulated 1.1-, 1.02-, 2.3-, 5.2- and 1.3-fold for the genes $K O, G A 200 X 1, G A 20 X 6, G A 20 X 8$ and GAIP, respectively, in the BP compared to the UBP, and with down-regulated 0.9- and 0.7-fold for the genes GA2OX1 and $G A /$ in the BP (Fig. 3A).

The 14 DEGs that are associated with photoperiodic induction include: CO3, COL2, COL3, COL 16, FTIP1, FD, HDR1, HD3A, MIP1A, MIP1B, CDF2, SVP, EFM and AS1 (Table 3). RPKM based expression values of the 14 genes were validated by qRT-PCR, and their RELs were observed to be consistent with RPKM values, with up-regulated 1.3-, 2.0-, 3.3-, 1.2-, 4.4-, 1.2-, 2.2-, 1.7-, 3.7- and 1.8-fold for the genes CO3, COL2, FTIP1, FD, HDR1, HD3A, MIP1A, MIP1B, CDF2 and EFM, respectively, in the BP compared to the UBP, and with down-regulated 0.7-, 0.98-, 0.9- and 0.8-fold for the genes COL3, COL 16, SVP and AS1 in the BP (Fig. 3B).

\section{Sucrose and GA Accumulation}

Flowering can be initiated by the accumulation of active $G A$ s including $\mathrm{GA}_{1}, \mathrm{GA}_{3}, \mathrm{GA}_{4}$ and $\mathrm{GA}_{7}$. Interestingly, $\mathrm{GA}_{4}$ and $\mathrm{GA}_{1}$ as well as the up-stream precursors $\mathrm{GA}_{9}$ and $\mathrm{GA}_{20}$ had a 3.0-, 1.3-, 5.4- and 4.2fold increase in $B P$ while the down-stream inactive forms of $\mathrm{GA}_{4}$ and $\mathrm{GA}_{1}, \mathrm{GA}_{8}$ had an 1.5-fold increase in UBP (Fig. $4 A$ ). Since $\mathrm{GA}_{1}$ and $\mathrm{GA}_{4}$ exhibit higher floral induction activity than other $\mathrm{GAs}$ that are produced in plants [21], an elevated level of $\mathrm{GA}_{1}$ and $\mathrm{GA}_{4}$ may promote EBF. In contrast, an almost 2-fold decrease 
in soluble sugars in the BP was unexpected as elevated sugar is usually a driver of flowering (Fig. 4B) [28].

\section{Discussion}

The SUPPRESSOR OF OVEREXPRESSION OF CONSTANS1 (SOC1) can integrate signals from the photoperiodism, vernalization, sucrose and GA pathways and regulate the expression of $L F Y$, which links floral induction and floral development, when associated with other MADS box genes [30]. MADS box proteins regulate different developmental processes including flowering time, floral meristem identity and floral organ development [31]. MADS8 that is structurally related to the AGL2 family is involved in controlling flowering time [32]. AGL8 promotes early floral meristem identity in synergy with $A P 1$ and CAULIFLOWER [33]. AGL 12 acts as promoter of the flowering transition through up-regulation of SOC, FT and $L F Y$ [34]. DEFICIENS (DEFA) is involved in the genetic control of floral development [35]. APETALA1 $(A P 1)$ and $A P 2$ are required for the transition of an inflorescence meristem into a floral meristem and promote early floral meristem identity, with $A P 1$ regulating positively $A G$ in cooperation with $L F Y$, while $A P 2$ repressing $A G$ by recruiting the transcriptional corepressor $T P L$ and $H D A 19[36,37]$. AINTEGUMENTA $(A N T)$, a member of the $A P 2$-like family, is involved in flower organs initiation and development and mediates $A G$ down-regulation [38, 39]. Positive regulators of flowering in the floral development pathway were observed to be up-regulated in EBF plants are while genes that disfavor flowering ( $A P 2$ and $A N T)$ were down-regulated, suggesting that transcription regulation of these genes may well be a driver for $A$. sinensis EBF.

Suc and its cleavage products glucose (Glc) and fructose (Fru) are central molecules for cellular biosynthesis and signal transduction throughout a plant's life cycle [40]. In this study, Suc synthases (SUSs) that are encoded by three SUS1, SUS3 and SUS7 genes catalyze a reversible conversion of Suc and UDP to UDP-Glc and Fru [41, 42]; Alkaline/neutral invertases (INVs) that are encoded by three INVA, INVB and INVE genes catalyze an irreversible hydrolysis of Suc to Glc and Fru [43-45]; and the invertase inhibitor (INV Inh) inhibits the INV activity by forming a complex with INV [46]. Two kinds of amylase enzymes including a-amylase (AMY) and $\beta$-amylase (BAM) could respectively produce a-maltose and $\beta$ maltose through the hydrolysis of amylopectin and amylose [47]. In this study, four DEGs encoding amylase enzymes include: AMY1.1 that can increase enzyme activity via accessory binding sites on the protein surface, BAM1 and BAM3 that play important roles in starch degradation and maltose metabolism and BAM9 is inactive due to lack the conserved Glu active site [47-49]. Since the genes (SUS1, SUS3, SUS7, INVA, INVB, INVE, AMY1.1, BAM1, BAM3 and BAM9) that flavor flowering were upregulated and the INV Inh gene that disflavors flowering was down-regulated, transcriptional regulation of sucrose pathway is consistent with EBF.

While genes associated with GA biosynthesis and GA mediated signaling were differentially regulated in $B P$ versus UBP, the genes did not exhibit coherent transcriptional regulation with $E B F$, suggesting that transcriptional regulation of GA mediated genes is not a driver of early bolting. For example, with GA mediated signaling, DELLA proteins GA-INSENSITIVE (GAI) and GAIP function as inhibitors by interacting 
in large multiprotein complexes that repress transcription of GA-inducible genes [50-52]. Inconsistent with promoting flowering, these genes are transcriptionally up-regulated in BP versus UBP. Inconsistency is also observed in genes that encode GA biosynthesis with a subset of genes up regulated such as $K O$, that catalyzes the conversion of ent-kaurene to kaurenoic acid early in the biosynthetic pathway [53] as well as GA200X1 that converts GA12/GA53 to GA9/GA20 [54] later in the pathway (Fig. S13), while GA2OX8 that catalyzes 2-beta-hydroxylation of GA precursors, rendering them unable to be converted to active GAs is up-regulated under the same condition that promotes flowering (BP). This incoherent transcriptional regulation of GA biosynthesis and signaling for EBF suggests that early bolting may be regulated by events downstream of flowering signaling such as GA and/or sugar accumulation.

While CONSTANS-LIKE (COL) genes are regulators in the photoperiod pathway and flowering, transcripts in this pathway were also inconsistently induced providing an inarticulate signal for plant flowering. For example, while both $\mathrm{CO} 3$ and $\mathrm{COL} 3$ function as floral activators, the two genes were transcriptionally upand down-regulated, respectively when comparing BP with UBP. Specifically, $\mathrm{CO} 3$ up regulates the expression of Heading date 3a (HD3A) and FLOWERING LOCUS T-LIKE (FTL) under LD conditions $[55,56]$. FT-interacting protein 1 (FTIP1) is an essential regulator required for the export of FT protein from the phloem companion cells to sieve elements through the plasmodesmata under LD conditions [57] and was observed to be up regulated in BP. The FT protein acts as a long-distance signal to induce flowering [58] and FLOWERING LOCUSD $(F D)$ interacts with FT protein to activate the downstream floral meristem identity genes $A P 1$ to initiate floral development $[59,60]$. While this is consistent with flower induction that is observed with $\mathrm{BP}$, there are several transcriptional responses that are not down-regulated at expected. For example, $C D F 2$ is a transcriptional repressor that delays flowering by repressing $C O$ transcription under LD conditions [25] was found to be up-regulated almost 4-fold in BP compared with UBP. MIP1A and MIP1B that repress flowering by forming heterodimeric complexes that sequester $\mathrm{CO}$ and $\mathrm{COL}$ proteins into non-functional complexes [26] were also found to be up-regulated in BP. Another inconsistent transcriptional response for flowering is up regulation of HEADING DATE REPRESSOR 1 (HDR1), a flowering suppressor that up-regulates HD1 in LD conditions [61]. Again, inconsistent regulation of photoperiod pathway transcripts associated with flowering in BP suggests down-stream signaling involvement in early bolting.

Flowering is a process in which plants transition from vegetative to reproductive growth via a complex pathway of signaling networks. The DEGs observed comparing BP and UBP suggests transcription-based regulation of EBF. Specifically, genes associated with floral development and sucrose signaling are transcriptionally correlated with bolting (Fig. 5). For the floral development, SOC1 can integrate signals from the photoperiodic, GA and sucrose pathways to initiate early floral meristem identity by regulating the over-expression of $L F Y$; meanwhile, $A P 1$ in synergy with MADS, AGL8 and $A G L 12$ that are repressed by $A P 2$ and $A N T$, promotes early floral meristem identity. Lastly, the early floral meristem identity induces early bolting and flowering of $A$. sinensis plants. For sugar signaling, over-expression of genes $A M Y 1.1$, $B A M 1$ and $B A M 3$ enhances starch degradation while differential expression SUSs, INVs and INVInh cleavage Suc to Glc and Fru that can also promote SOC1 expression. 


\section{Conclusions}

The DEGs observed comparing BP and UBP suggests transcription-based regulation of EBF. This transcriptomic and analysis focuses on four pathways that can mediate a transition from vegetative to reproductive growth: photoperiodic, GA signaling, autonomous and floral development. While genes associated with EBF have been identified and mapped here, a causative role of these genes in activating and/or regulating EBF will require the knocking out of specific genes via a CRISPR-Cas 9 system.

\section{Methods}

\section{Plant material}

Mature seeds of 3-year-old A. sinensis (Mingui No. 1) (family Apiaceae, alt. Umbelliferae) were permitted to collect from the county-owned garden located in Minxian county $\left(2,520 \mathrm{~m}\right.$ asl; $34^{\circ} 28^{\prime} 33^{\prime \prime} \mathrm{N}$, $\left.104^{\circ} 05^{\prime} 51^{\prime \prime} \mathrm{E}\right)$ of Gansu province, P. R. China in July 2017. The species was identified by professor ling Jin (Gansu University of Chinese Medicine, Lanzhou, Gansu, China). A voucher specimen (No. 20200182) was deposited in the herbarium of College of Life Science and Technology, Gansu Agricultural University, Lanzhou, Gansu, China. Seeds were pre-treated in water $\left(30^{\circ} \mathrm{C}\right)$ for $24 \mathrm{hrs}$. and sown at a soil depth of 0.5 cm located in Minxian county (2,730 m asl; $\left.34^{\circ} 28^{\prime} 8^{\prime \prime} \mathrm{N}, 104^{\circ} 36^{\prime} 22^{\prime \prime} \mathrm{E}\right)$ in June 2018 . Seedlings were dug up in October 2018, aired in the shade for approximately 15 days and then stored in a natural-rain-proof environment for the winter.

On April 3, 2019, the stored seedlings (root tip diameter 4.5-5.0 mm) were transplanted into pots (diameter $17 \mathrm{~cm}$, depth $20 \mathrm{~cm}$; one seedling per pot) with nutrition matrix and seedlings were greenhouse grown with controlling matrix volumetric moisture content of $60 \%-70 \%$, light condition of $10-12 \mathrm{hrs}$. per day and air temperature $15-22^{\circ} \mathrm{C}$. No additional fertilizer was applied after the transplant. On July 3,2019 , samples including the second-tip leaves and lateral roots (1:1, g/g fresh weight) from BP and UBP (Fig.S10) were collected ( $n=20$ plants) and then flash frozen in liquid nitrogen for transcriptomic analysis and GA metabolite analysis.

\section{Total RNA isolation and Illumina sequencing}

Total RNA samples were extracted using a Trizol reagent, enriched using Oligo (dT) beads (Invitrogen, CA, USA), fragmented into short mRNA segments (200-700 nt) using a fragmentation buffer and reverse transcribed into cDNA with random primers. Second-strand cDNA was synthesized via DNA polymerase I, RNase $\mathrm{H}$, dNTP and buffer and cDNA fragments were purified using a QiAquick PCR extraction kit, successively repaired-end, added poly ( $A$ ), and ligated to Illumina sequencing adapters. Finally, the ligation products were sequenced using an Illumina HiSeq ${ }^{\mathrm{TM}} 4000$ platform by Gene Denovo Biotechnology Co., Ltd. (Guangzhou, China). 


\section{Sequence filtration, assembly and unigene expression analysis}

Raw reads obtained from the Illumina sequencing were further filtered to get high quality clean reads by removing reads containing adapters, more than $10 \%$ unknown nucleotides as well as more than $40 \%$ low quality (Q-value $\leq 10$ ) bases. De novo assembly of clean reads was carried out using Trinity software [62] that combined three components: Inchworm, Chrysalis and Butterfly, respectively for assembling a collection of linear contigs, building graphs for each cluster of related contigs and outputting one linear sequence for each alternatively spliced isoform and transcripts. The expression level of each transcript was calculated and normalized to reads per kb per million reads (RPKM) [63]. In this study, the level of differential expression for each transcript with a criterion of $\| \log _{2}$ (fold-change) $\geq 1$ and $p$ value $\leq 0.05$ to identify DEGs between BP and UBP.

\section{Basic annotation of DEGs and gene cluster analysis}

Unigenes were annotated against the databases including: NCBI non-redundant protein (NR), Swiss-Prot protein, Kyoto Encyclopedia of Genes and Genomes (KEGG), euKaryotic orthologous groups of proteins (KOG), and gene ontology (GO) by using a BLASTx procedure with an e-value $\leq 10^{-5}$ [64]. Molecular Evolutionary Genetics Analysis (MEGA) 7.0 was used for the gene cluster analysis (Fig. S11).

\section{qRT-PCR validation}

Total RNA samples from samples of the BP and UBP plants were extracted using a plant RNA kit. Primer sequences of the 40 DEGs (Table 4) were designed with the tools for primer-blast in NCBI. First-strand cDNA was synthesized using a FastKing RT kit with one cycle at $42^{\circ} \mathrm{C}$ for $15 \mathrm{~min}$ and then $95^{\circ} \mathrm{C}$ for 3 min. PCR amplification was carried out using a SuperReal PreMix with one cycle at $95^{\circ} \mathrm{C}$ for $15 \mathrm{~min}$, followed by 40 cycles at $95^{\circ} \mathrm{C}$ for $10 \mathrm{~s}, 60^{\circ} \mathrm{C}$ for $20 \mathrm{~s}$ and $72^{\circ} \mathrm{C}$ for $30 \mathrm{~s}$. Melting curves were analyzed after an incubation at $72^{\circ} \mathrm{C}$ for $34 \mathrm{~s}$. Actin was used as an internal standard, the relative expression level (REL) of gene was calculated based on a $2^{\square \Delta \Delta C t}$ method [65].

\section{GA quantification and identification}

Five GAs including $\mathrm{GA}_{1}, \mathrm{GA}_{4}, \mathrm{GA}_{8}, \mathrm{GA}_{9}$ and $\mathrm{GA}_{20}$ were quantified and identified using a HPLC (Agilent1290, USA)-MS/MS (QTRAP 6500, AB SCIEX, USA) by Shanghai Biotree biotech Co., Ltd. (Shanghai, China). Representative chromatograms of reference standard of the $5 \mathrm{GAs}$ are shown in Fig. S12, and representative chromatograms of the BP and UBP are shown in Fig. S13. The content of the 5 GAs was calculated based on calibration curves (Table S1). 


\section{Soluble sugar measurement}

Soluble sugar was measured using a sulfuric acid-phenol protocol [66]. A dried powder (1.0 g) was soaked in $10 \% \mathrm{EtOH}(25 \mathrm{~mL})$ for $72 \mathrm{hrs}$. at $22^{\circ} \mathrm{C}$ and then centrifuged $\left(4^{\circ} \mathrm{C}, 8000 \mathrm{r} / \mathrm{min}, 10 \mathrm{~min}\right)$. Extracts $(30 \mu \mathrm{L})$ were added into $9 \%$ phenol reagent $(1 \mathrm{~mL})$, sulfuric acid $(3 \mathrm{~mL})$ was added after oscillation and then reacted at $22^{\circ} \mathrm{C}$ for $30 \mathrm{~min}$. Absorbance was measured at $485 \mathrm{~nm}$, soluble sugar content was evaluated based on $\mathrm{mg}$ of Suc.

\section{Statistical analysis}

All the measurements were performed using three replicates. A t-test for independent samples was performed and SPSS 22.0 was used, with $p \rrbracket 0.05$ as the basis for significant differences.

\section{Abbreviations}

EBF: early bolting and flowering; BP: bolted plants; UBP: unbolted plants; DEGs: differentially expressed genes; asl: above sea level; GA: gibberellin; LD: long-day; RPKM: reads per kb per million reads; NR: NCBI non-redundant protein; KEGG: Kyoto Encyclopedia of Genes and Genomes; KOG: euKaryotic orthologous groups of proteins; GO: gene ontology; MEGA: Molecular Evolutionary Genetics Analysis; REL: relative expression level.

\section{Declarations}

\section{Acknowledgments}

Thanks to Gene Denovo Biotechnology Co., Ltd. (Guangzhou, China) and Shanghai Biotree biotech Co., Ltd. (Shanghai, China) for their technical assistance, we also thank Gansu Herbal Medicine Planting Co., Ltd. (Lanzhou, China) for providing A. sinensis seeds.

\section{Authors' contributions}

ML and JW conceived and designed the study. JL, HX and DY performed all the experiments and analyzed the transcriptome data. ML, PWP, RY and LJ wrote the manuscript. All authors read and approved the final manuscript.

\section{Funding}

This work was financially supported by funds from the National Industrial System of Traditional Chinese Medicine (CARS-21), Gansu Agricultural University (GSCS-2018-1 and Gaufx-02J04), and Key talent projects of Gansu Province (2020RCXM103). 


\section{Availability of data and materials}

The datasets generated during the current study are publicly available at National Center for Biotechnology Information (NCBI), with BioSample: SAMN13379532 and SRA: SRR10524260 to SRR10524265 (https://dataview.ncbi.nlm.nih.gov/object/PRJNA591308?

reviewer=pthe4ktocjjigtmm0dh136aa9t).

\section{Ethics approval and consent to participate}

Not applicable.

\section{Consent for publication}

Not applicable.

\section{Competing interests}

The authors declare that there is no conflict of interest regarding the publication of this paper.

\section{Author details}

${ }^{1}$ Institute of Medicinal Plant Development, Chinese Academy of Medical Sciences \& Peking Union Medical College, Beijing, 100193, China. ${ }^{2}$ Key Lab of Arid Land Crop Science, Gansu Agricultural University, Lanzhou 730070, China. ${ }^{3}$ Department of Chemistry and Biochemistry, Texas Tech University, Texas 79409, USA. ${ }^{4}$ College of Pharmacy, Gansu University of Chinese Medicine, Lanzhou 730000, China.

\section{References}

1. Li MF, Liu XZ, Wei JH, Zhang Z, Chen SJ, Liu ZH, Xing H. Selection of high altitude planting area of Angelica sinensis based on biomass, bioactive compounds accumulation and antioxidant capacity. Chin. Tradit. Herbal Drugs. 2020;51(2):474-481.

2. Xu XQ, Zhang XB, Chen J, Zhao WL, Jin L. Study on ecological suitability of Angelica sinensis in Gansu Province. Chin. Tradit. Herbal Drugs. 2020;51(12):3304-3307.

3. Zhang HY, Bi WG, Yu Y, Liao WB. Angelica sinensis (Oliv.) Diels in China: distribution, cultivation, utilization and variation. Genet. Resour. Crop Evol. 2012;59:607-613.

4. Ma JP, Guo ZB, Jin L, Li Phytochemical progress made in investigations of Angelica sinensis (Oliv.) Diels. Chin. J. Nat. Med. 2015;13(4):241-249. 
5. Wei WL, Zeng R, Gu CM, Qu Y, Huang LF. Angelica sinensis in China-A review of botanical profile, ethnopharmacology, phytochemistry and chemical analysis. J. Ethnopharmacol. 2016;190:116-141.

6. Chao WW, Hong $\mathrm{YH}$, Chen ML, Lin Inhibitory effects of Angelica sinensis ethyl acetate extract and major compounds on NF-KB trans-activation activity and LPS-induced inflammation. J. Ethnopharmacol. 2010;129:244-249.

7. Kan WLT, Cho CH, Rudd JA, Lin Study of the anti-proliferative effects and synergy of phthalides from Angelica sinensis on colon cancer cells. J. Ethnopharmacol. 2008;120:36-43.

8. Wang LY, Tang YP, Liu X, Zhu M, Tao WW, Li WX, Duan JA. Effects of ferulic acid on antioxidant activity in Angelicae sinensis Radix, Chuan xiong Rhizoma, and their combination. J. Nat. Med. 2015;13(6):401-408.

9. Wang BH, Ou-Yang JP. Pharmacological actions of sodium ferulate in cardiovascular system. Cardiovasc. Drug Rev. 2005;23(2):161-172.

10. Zhou WJ, Wang S, Hu Z, Zhou ZY, Song CJ. Angelica sinensis polysaccharides promotes apoptosis in human breast cancer cells via CREB-regulated caspase-3activation. Biochem. Biophys. Res. Commun. 2015;467(3):562-569.

11. Huang LQ, Jin L. Suitable technology for production and processing of Angelica sinensis. Beijing: China Pharmaceutical Science and Technology Press. 2018;pp:1-14.

12. Zhang Z, Liu XZ, Bao YJ, Li J, Cao XL, Li MF. Selection of cropping rotations of Angelica sinensis based on biomass, bioactive compounds accumulation and antioxidant capacity. J. Gansu Agr. Univ. 2018;53(6):86-89.

13. Qi JT, Lin HM, Liu XZ. Preliminary study on the effect of nitrogen and phosphorus fertilizer on bolting rate of Angelica sinensis. J. Chin. Med. Mater. 2004; 27(2):82-83.

14. Qiu DY, Lin HM, Chen Y, Li YD, Guo FX. Effects of latitude, longitude and altitude on Angelica growth and early bolting in medicine formation period. Acta Agrestia Sin. $2010 \mathrm{a} ; 18(6): 838-843$.

15. Qiu DY, Lin HM, Fang ZS, Li Effects of seedlings with different root diameters on Angelica sinensis early bolting and physiological changes during the medicine formation period. Acta Pratac. Sin. $2010 \mathrm{~b} ; 19(6): 100-105$.

16. Wang WJ. Analysis and control of early bolting characteristic of Angelica sinensis. J. Northwest Uuiv. (Nat. Sci. Ed.). 1977;7(2):32-39.

17. Wang WJ. Technology and principle of seedling frozen storage of Angelica sinensis. Chin. Med. Mat. 1979;3:1-4.

18. Lin HM, Wu YA, Cao ZF, Lv SL, Mao XJ. Influence of sun shade cultivation on premature bolting in Angelica sinensis and growth environment factors. Chin. J. Exp. Trad. Med. Formula. 2010;16(4):7983.

19. Li MS, Yu ZY. Research on prevention of early bolting of Angelica sinensis. Chin. Tradit. Herbal Drugs. 1979;57(12):34-38, 49. 
20. Michaels SD, Amasino RM. Memories of winter: Vernalization and the competence to flower. Plant Cell Environ. 2000;23:1145-1154.

21. Taiz L, Zeiger Plant physiology (Fifth Edition). Prue. D. V., Fosket. D. E., Amasino, R.. The control of flowering. Sinauer Associates, Inc., Sunderland. 2010;pp: 569-596.

22. Chen L, Cheng JC, Castle L, and Sung ZR. EMF genes regulate Arabidopsis inflorescence development. Plant Cell. 1997;9:2011-2024.

23. Goodrich J, Puangsomlee P, Martin M, Long D, Meyerowitz EM, and Coupland G. A Polycomb-group gene regulates homeotic gene expression in Arabidopsis. Nature. 1997;386:44-51.

24. Piñeiro M, Gómez-Mena C, Schaffer R, Martínez-Zapater JM, Coupland G. EARLY BOLTING IN SHORT DAYS is related to chromatin remodeling factors and regulates flowering in Arabidopsis by repressing FT. Plant Cel. 2003;15(7):1552-1562.

25. Fornara F, Panigrahi KC, Gissot L, Sauerbrunn N, Ruehl M, Jarillo JA, Coupland G. Arabidopsis DOF transcription factors act redundantly to reduce CONSTANS expression and are essential for a photoperiodic flowering response. Dev. Cell. 2009;17:75-86.

26. Graeff M, Straub D, Eguen T, Dolde U, Rodrigues V, Brandt R, Wenkel S. Microprotein-mediated recruitment of CONSTANS into a TOPLESS trimeric complex represses flowering in Arabidopsis. Plos Genet. 2016;12:e1005959.

27. Zhang EH, Huang P. Effects of vernalization treatment on physiological character of Angelica sinensis J. Gansu Agr. Univ. 1998;33(3):240-243.

28. Lu ZQ, Zhang JW, Ren LR, Huang HY, Ma ZC, Qi Analysis on physiological and biochemical characteristics of bolting Angelica sinensis plant. Chin. Tradit. Herbal Drugs. 2011;42(11): 23262329.

29. Yu G, Zhou Y, Yu JJ, Hu XQ, Tang Y, Yan H, Duan JA. Transcriptome and digital gene expression analysis unravels the novel mechanism of early flowering in Angelica sinensis. Sci. Rep. 2019;9:10035.

30. Lee J, Oh M, Park H, Lee SOC1 translocated to the nucleus by interaction with AGL24 directly regulates leafy. Plant J. 2008;55:832-843.

31. Theissen G, Becker A, Di Rosa A, Kanno A, Kim JT, Munster T, Winter KU and Saedler A short history of MADS-box genes in plants. Plant Mol. Biol. 2000;42:115-149.

32. Kang HG, Jang S, Chung JE, Cho YG, An G. Characterization of two rice MADS box genes that control flowering time. Mol. Cells. 1997;7:559-566.

33. Ferrandiz C, Gu Q, Martienssen R, Yanofsky F. Redundant regulation of meristem identity and plant architecture by FRUITFULL, APETALA1 and CAULIFLOWER. Development. 2000;127:725-734.

34. Tapia-Lopez R, Garcia-Ponce B, Dubrovsky JG, Garay-Arroyo A, Perez-Ruiz RV, Kim SH, Acevedo F, Pelaz S, Alvarez-Buylla An AGAMOUS-related MADS-box gene, XAL1 (AGL12), regulates root meristem cell proliferation and flowering transition in Arabidopsis. Plant Physiol. 2008;146:11821192. 
35. Sommer H, Beltrán JP, Huijser P, Pape H, Lönnig WE, Saedler H, Schwarz-Sommer Deficiens, a homeotic gene involved in the control of flower morphogenesis in Antirrhinum majus: the protein shows homology to transcription factors. EMBO J. 1990;9(3):605-613.

36. Gregis V, Sessa A, Dorca-Fornell C, Kater MM. The Arabidopsis floral meristem identity genes AP1, AGL24 and SVP directly repress class B and C floral homeotic genes. Plant J. 2009;60:626-637.

37. Krogan NT, Hogan K, Long APETALA2 negatively regulates multiple floral organ identity genes in Arabidopsis by recruiting the co-repressor TOPLESS and the histone deacetylase HDA19. Development. 2012;139:4180-4190.

38. Elliott RC, Betzner AS, Huttner E, Oakes MP, Tucker WQJ, Gerentes D, Perez P, Smyth AINTEGUMENTA, an APETALA2-like gene of Arabidopsis with pleiotropic roles in ovule development and floral organ growth. Plant Cell. 1996;8:155-168.

39. Krizek BA, Prost V, Macias AINTEGUMENTA promotes petal identity and acts as a negative regulator of AGAMOUS. Plant Cell. 2000;12:1357-1366.

40. Smeekens S, Ma J, Hanson J, Rolland F. Sugar signals and molecular networks controlling plant growth. Opin. Plant Biol. 2010;3:273-278.

41. Angeles-Nunez JG, Tiessen A. Arabidopsis sucrose synthase 2 and 3 modulate metabolic homeostasis and direct carbon towards starch synthesis in developing seeds. Planta. 2010; 232:701718.

42. Geigenberger $P$, Stitt M. Sucrose synthase catalyzes a readily reversible-reaction in vivo in developing potato tubers and other plant tissues. Planta. 1993;189:329-339.

43. Tamoi M, Tabuchi T, Demuratani M, Otori K, Tanabe N, Maruta T, Shigeoka S. Point mutation of a plastidic invertase inhibits development of the photosynthetic apparatus and enhances nitrate assimilation in sugar-treated Arabidopsis seedlings. J. Biol. Chem. 2010;285:15399-15407.

44. Vargas WA, Pontis HG, Salerno GL. New insights on sucrose metabolism: evidence for an active A/NInv in chloroplasts uncovers a novel component of the intracellular carbon trafficking. Planta. 2008; 227:795-807.

45. Xiang L, Le Roy K, Bolouri-Moghaddam MR, Vanhaecke M, Lammens W, Rolland F, Van den Ende W. Exploring the neutral invertase-oxidative stress defence connection in Arabidopsis thaliana. J. Exp. Bot. 2011;62:3849-3862.

46. Rausch T, Greiner S. Plant protein inhibitors of invertases. Biochim. Biophys. Acta. 2004;1696:253261.

47. Fulton DC, Stettler M, Mettler T, Vaughan CK, Li J, Francisco P, Gil M, Reinhold H, Eicke S, Messerli G, Dorken G, Halliday K, Smith AM, Smith SM, Zeeman SC. Beta-AMYLASE4, a noncatalytic protein required for starch breakdown, acts upstream of three active beta-amylases in Arabidopsis chloroplasts. Plant Cell. 2008;20:1040-1058.

48. Edner C, Li J, Albrecht T, Mahlow S, Hejazi M, Hussain H, Kaplan F, Guy C, Smith SM, Steup M, Ritte G. Glucan, water dikinase activity stimulates breakdown of starch granules by plastidial beta-amylases. Plant Physiol. 2007;145(1):17-28. 
49. Lu Y, Gehan JP, Sharkey TD. Daylength and circadian effects on starch degradation and maltose metabolism. Plant Physiol. 2005;138:2280-2291.

50. Blázquez MA, Weigel D. Integration of floral inductive signals in Arabidopsis. Nature. 2000;404:889892.

51. Fu X, Sudhakar D, Peng J, Richards DE, Christou P, Harberd NP. Expression of Arabidopsis GAI in transgenic rice represses multiple gibberellin responses. Plant Cell. 2001;13:1791-1802.

52. Fukazawa J, Teramura H, Murakoshi S, Nasuno K, Nishida N, Ito T, Yoshida M, Kamiya Y, Yamaguchi S, Takahashi Y. DELLAs function as coactivators of GAI-ASSOCIATED FACTOR1 in regulation of gibberellin homeostasis and signaling in Arabidopsis. Plant Cell. 2014;26:2920-2938.

53. Morrone D, Chen X, Coates RM, Peters RJ. Characterization of the kaurene oxidase CYP701A3, a multifunctional cytochrome P450 from gibberellin biosynthesis. Biochem. J. 2010;431:337-344.

54. Rieu I, Ruiz-Rivero O, Fernandez-Garcia N, Griffiths J, Powers SJ, Gong F, Linhartova T, Eriksson S, Nilsson O, Thomas SG, Phillips AL, Hedden P. The gibberellin biosynthetic genes AtGA20ox1 and AtGA20ox2 act, partially redundantly, to promote growth and development throughout the Arabidopsis life cycle. Plant J. 2008;53:488-504.

55. Kojima S, Takahashi Y, Kobayashi Y, Monna L, Sasaki T, Araki T, Yano M. Hd3a, a rice ortholog of the Arabidopsis FT gene, promotes transition to flowering downstream of Hd1 under short-day conditions. Plant Cell Physiol. 2002;43:1096-1105.

56. Kim SK, Yun CH, Lee JH, Jang YH, Park HY, Kim JK. OsCO3, a CONSTANS-LIKE gene, controls flowering by negatively regulating the expression of FT-like genes under SD conditions in rice. Planta.2008;228:355-365.

57. Liu L, Liu C, Hou X, Xi W, Shen L, Tao Z, Wang Y, Yu H. FTIP1 is an essential regulator required for florigen transport. Plos Biol. 2012;10(4):e1001313.

58. Corbesier L, Vincent C, Jang S, Fornara F, Fan Q, Searle I, Giakountis A, Farrona S, Gissot L, Turnbull C, Couplandet G. FT protein movement contributes to long-distance signaling in floral induction of Arabidopsis. Science. 2007;316:1030-1033.

59. Abe M, Kobayashi Y, Yamamoto S, Daimon Y, Yamaguchi A, Ikeda Y, Ichinoki H, Notaguchi M, Goto K, Araki T. FD, a bZIP protein mediating signals from the floral pathway integrator FT at the shoot apex. Science. 2005;309:1052-1056.

60. Wigge PA, Kim MC, Jaeger KE, Busch W, Schmid M, Lohmann JU, Weigel D. Integration of spatial and temporal information during floral induction in Arabidopsis. Science. 2005;309:1056-1059.

61. Sun X, Zhang Z, Wu J, Cui X, Feng D, Wang K, Xu M, Zhou L, Han X, Gu X, Lu T. The Oryza sativa regulator HDR1 associates with the kinase OsK4 to control photoperiodic flowering. Plos Genet. 2016;12:e1005927.

62. Grabherr MG, Haas BJ, Yassour M, Levin JZ, Thompson DA, Amit I, Adiconis X, Fan L, Raychowdhury R, Zeng Q, Chen Z, Mauceli E, Hacohen N, Gnirke A, Rhind N, di Palma F, Birren BW, Nusbaum C, Lindblad-Toh K, Friedman N, Regev A. Full-length transcriptome assembly from RNA-Seq data without a reference genome. Biotechnol. 2011;29(7):644-652. 
63. Mortazavi A, Williams B, McCue K, Schaeffer L, Wold B. Mapping and quantifying mammalian transcriptomes by RNA-Seq. Nat. Methods. 2008;5(7): 621-628.

64. Conesa A, S Gotz, Garcia-Gomez JM, Terol J, Talon M, Robles M. Blast2GO: a universal tool for annotation, visualization and analysis in functional genomics research. Bioinformatics. 2005;21(18): 3674-3676.

65. Willems E, Leyns L, Vandesompele J. Standardization of real-time PCR geneexpression data from independent biological replicates. Anal. Biochem. 2008;379,127-129.

66. Dubois M, Gilles KA, Hamilton JK, Rebers PA, Smith F. Colorimetric method for determination of sugars and related substances. Anal. 1956;28(3):350-356.

\section{Figures}

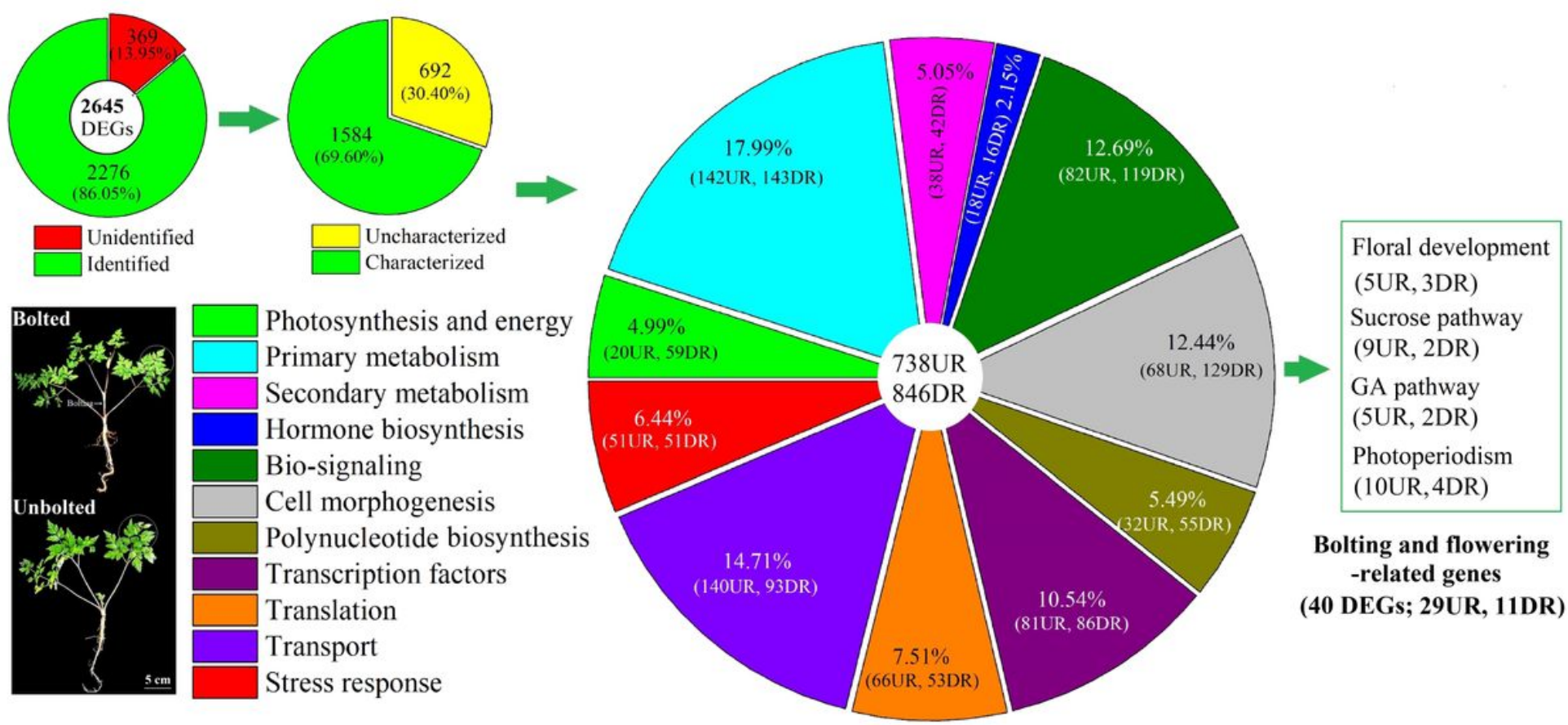

\section{Figure 1}

Distribution and classification of differentially expressed genes (DEGs) in bolted versus unbolted $A$. sinensis (UR, up-regulation; DR, down-regulation). 


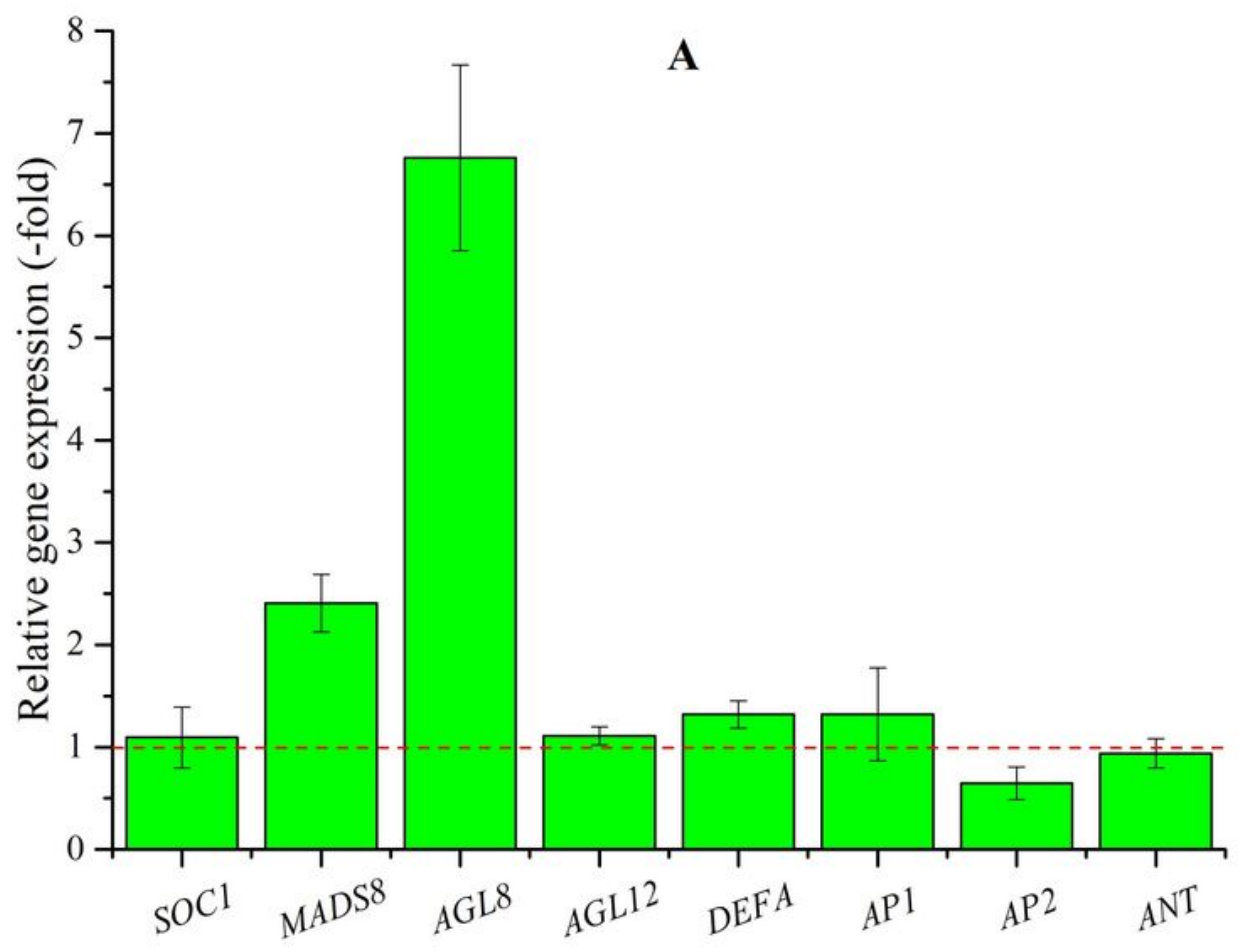

Genes associated with floral development

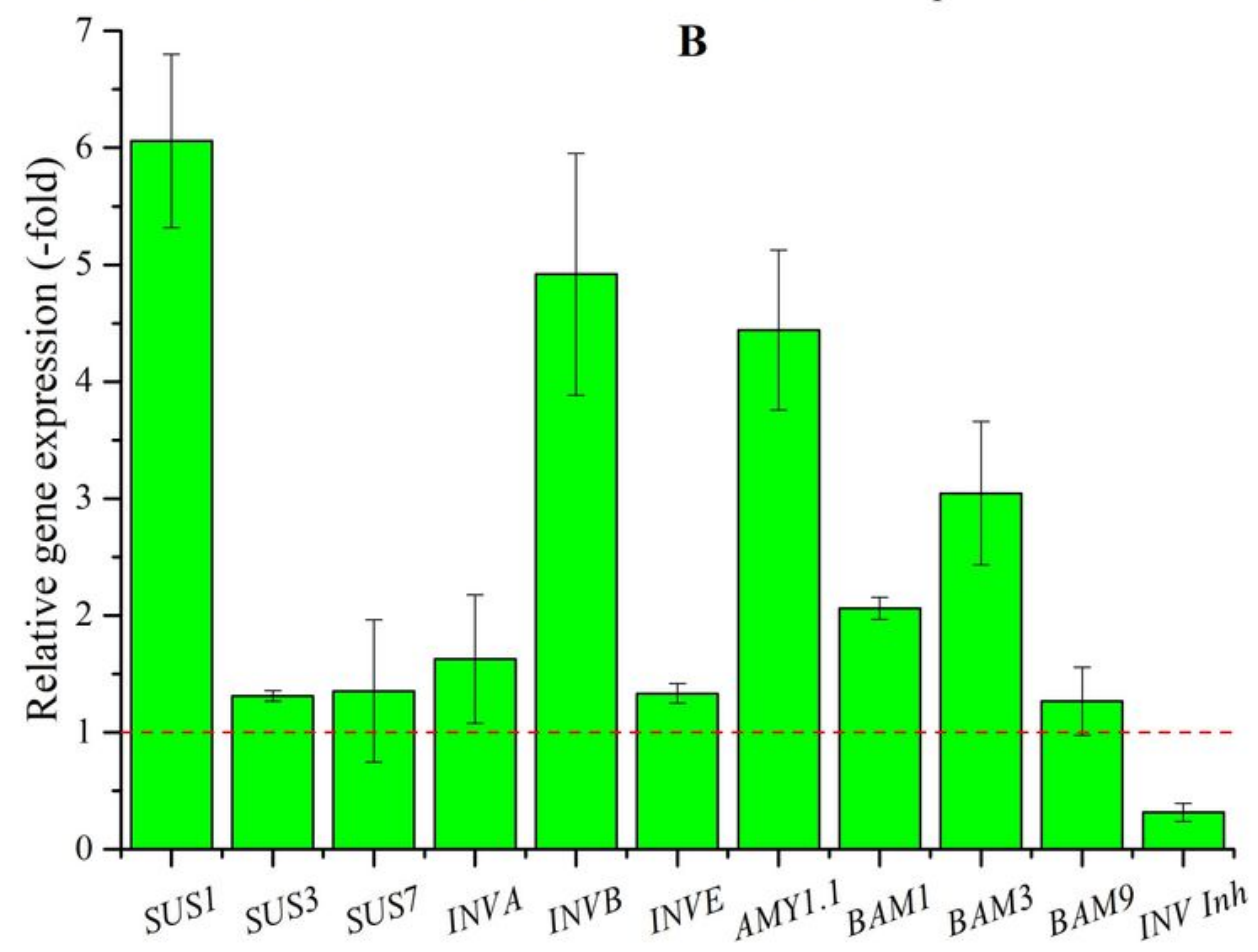

Genes associated with sucrose pathway

\section{Figure 2}

The relative expression level of genes associated with floral development (A) and sucrose pathway (B) in bolted compared with unbolted plants, as determined by qRT-PCR. 

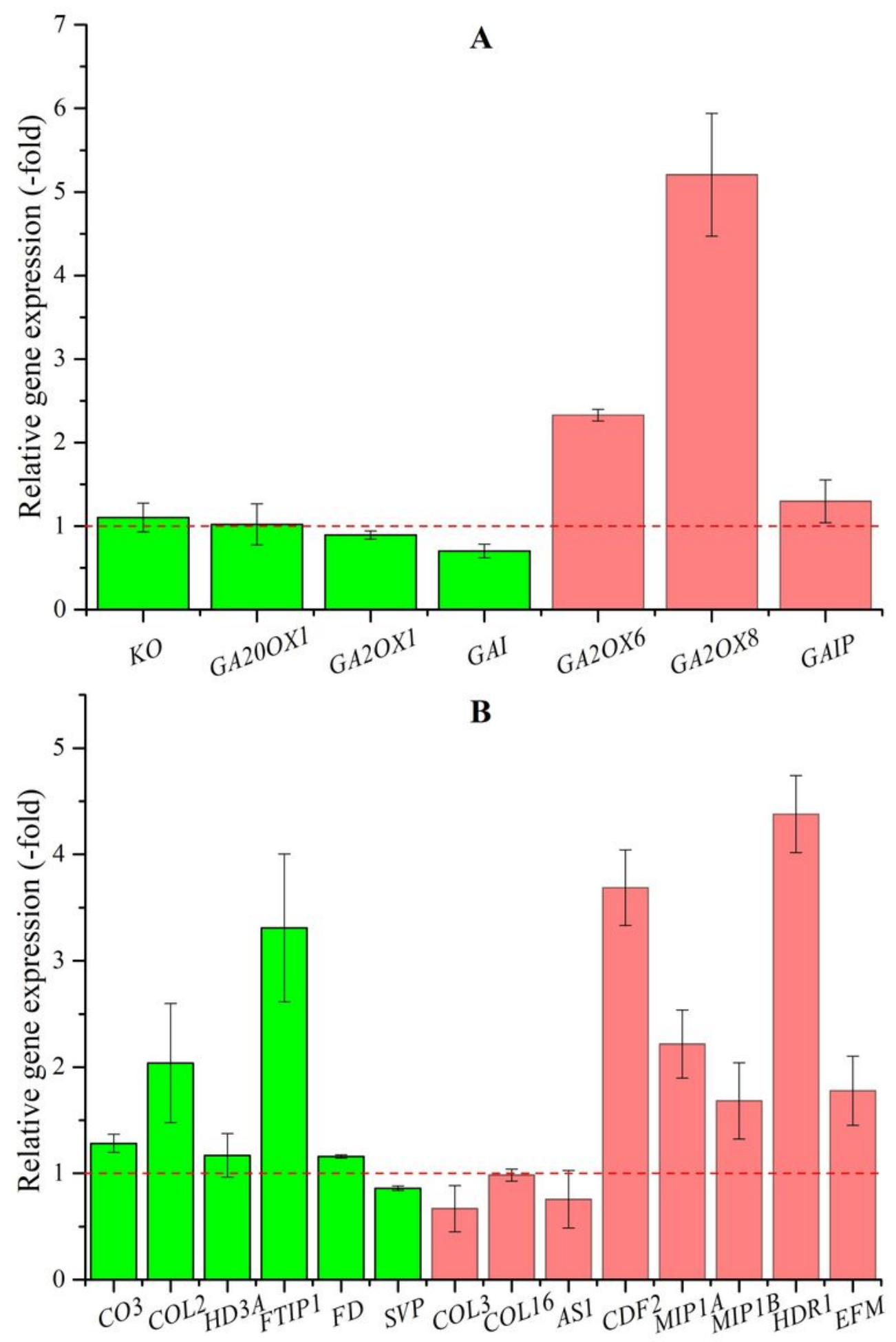

Genes associated with photoperiodic induction

\section{Figure 3}

The relative expression level of genes associated with GA (A) and photoperiodic pathways (B) in bolted compared with unbolted plants, as determined by qRT-PCR. Column highlighted in green represents favor flowering and red represents disfavor flowering. 

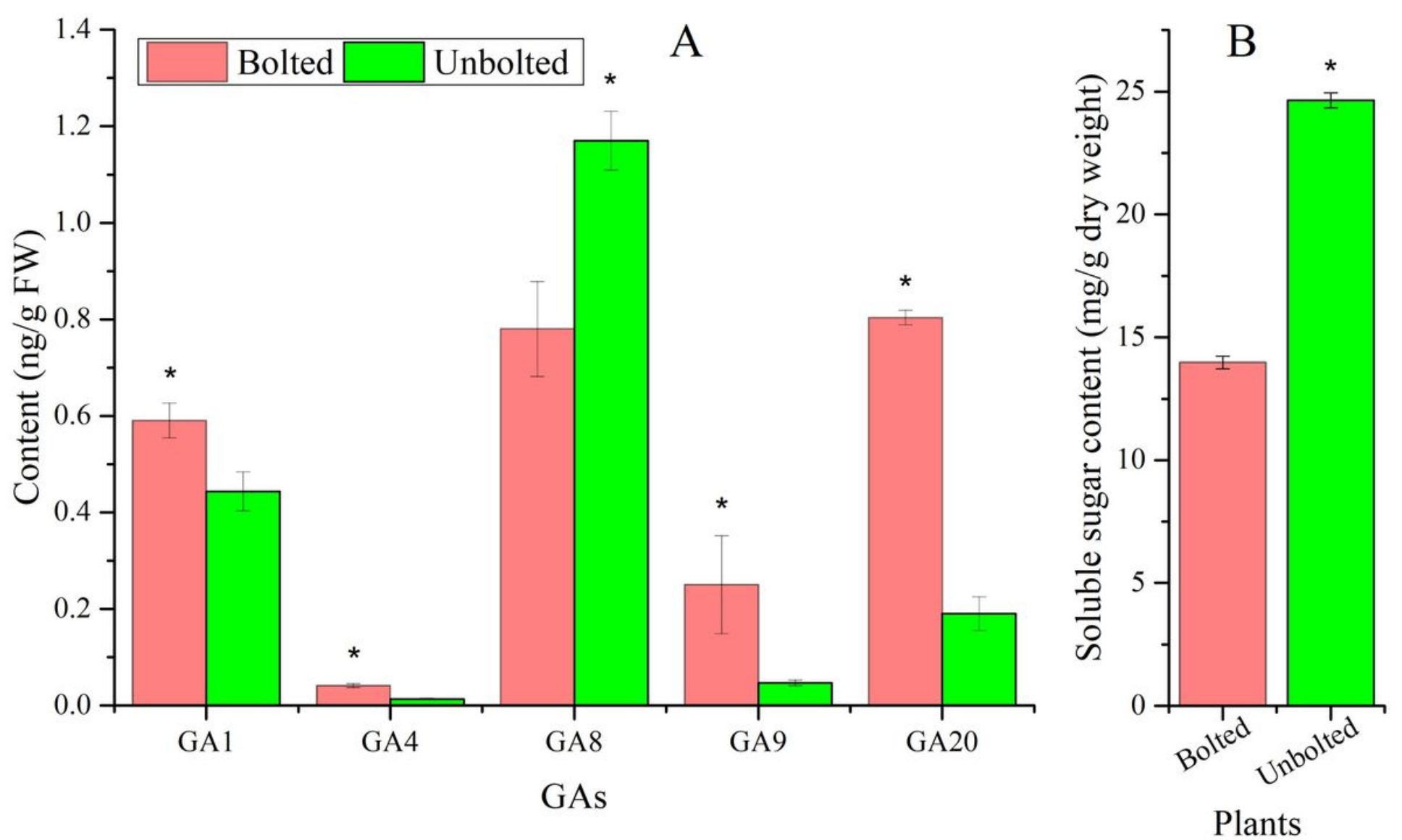

Figure 4

The contents of GAs (A) and soluble sugar (B) in bolted and unbolted plants, as determined by HPLCMS/MS. An asterisk (*) represents a significant difference (P凶0.05) between BP and UBP. 
Photoperiodic pathway

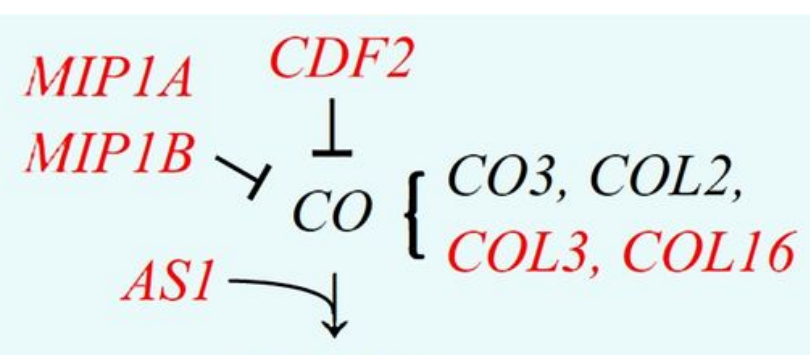

COIASI

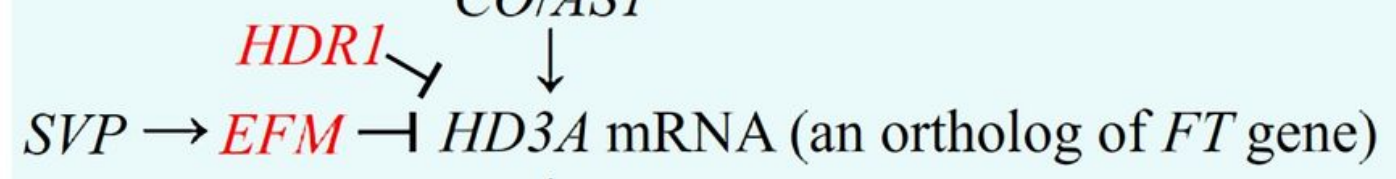

GA pathway

KO, GA20OX1, GA2OX1, GA2OX6, GA2OX8, GAI, GAIP

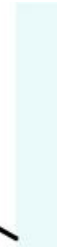

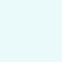

HD3A protein (phloem companion cells) FTIP1 $\downarrow$

HD3A protein (sieve elements)

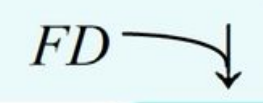

\section{HD3A/FD}

SUS1, SUS3, SUS7,

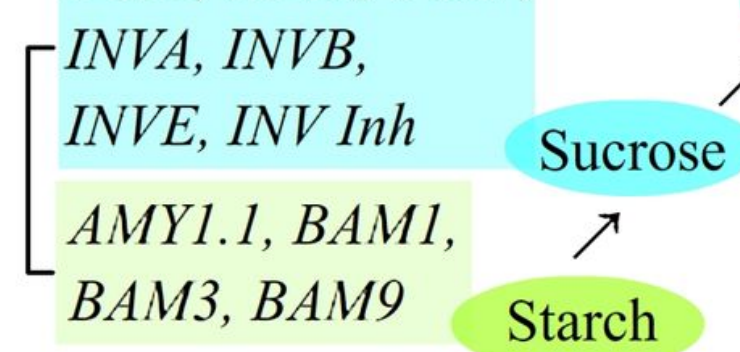

\section{Sucrose pathway}

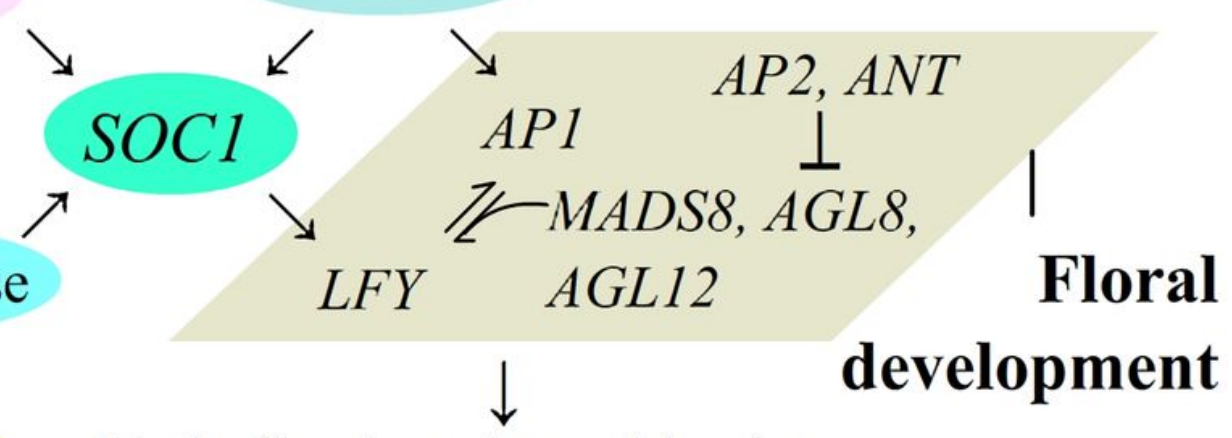

Early floral meristem identity

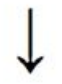

Early bolting and flowering

Figure 5

Schematic representation of speculated pathways of DEGs for regulating early bolting and flowering in A. sinensis. Genes highlighted in black represents favor flowering and red represents disfavor flowering.

\section{Supplementary Files}

This is a list of supplementary files associated with this preprint. Click to download.

- SupplementaryMaterials.docx 